\title{
Analysis of Selected Pesticide Residues and Heavy Metals in Honey Obtained from Plateau State, Nigeria
}

\author{
Gunat J. Lekduhur ${ }^{1}$, Peter 0. Onuwa ${ }^{2 *}$, Ishaq S. Eneji ${ }^{2}$, Sha'Ato Rufus ${ }^{2}$ \\ ${ }^{1}$ Department of Chemistry, Federal College of Forestry, Jos, Nigeria \\ ${ }^{2}$ Department of Chemistry/Centre for Agrochemical Technology and Environmental Research, Federal University of Agriculture, \\ Makurdi, Nigeria \\ Email: * peteronuwa@yahoo.com
}

How to cite this paper: Lekduhur, G.J., Onuwa, P.O., Eneji, I.S. and Rufus, S. (2021) Analysis of Selected Pesticide Residues and Heavy Metals in Honey Obtained from Plateau State, Nigeria. Journal of Analytical Sciences, Methods and Instrumentation, 11, 1-13.

https://doi.org/10.4236/jasmi.2021.111001

Received: March 1, 2021

Accepted: March 28, 2021

Published: March 31, 2021

Copyright $\odot 2021$ by author(s) and Scientific Research Publishing Inc. This work is licensed under the Creative Commons Attribution International License (CC BY 4.0).

http://creativecommons.org/licenses/by/4.0/

\begin{abstract}
Honey bees derive their nutrients from nectars and other plant materials. These naturally available materials are affected by the residual presence of pesticides. The concentration of pesticides in honey comb then reflects the leftover after degradation. In this study, samples of honey were collected from five different farms in Plateau State and analyzed for pesticide residues (atrazine, cypermethrin) and heavy metals ( $\mathrm{Pb}, \mathrm{Cd}, \mathrm{Cr}, \mathrm{Fe}$ and $\mathrm{Mn}$ ) using GC-MS and AAS techniques. Results of the analysis indicated that atrazine and cypermethrin were found in the range $(0.01-0.36$ and $0.11-0.26) \mathrm{mg} / \mathrm{kg}$, respectively in all the samples. Mn and Fe were found across the samples while $\mathrm{Cd}$ was detected only in the sample obtained from Maraban Jos (0.0013 $\mathrm{mg} / \mathrm{kg}$ ). Except Bokkos and Maraban Jos, $\mathrm{Pb}$ was detected in other samples. This study revealed that all samples contained the selected pesticide residues above the maximum residue limits recommended by European Union, while concentration of heavy metals in all the samples except Mn was below the maximum concentration limits recommended by Food and Agriculture Organization. The high concentration of pesticide residues in the samples indicates contaminated environment in which the bees fed; therefore intermittent monitoring of the quality of honeys produced would be necessary as this calls for urgent attention.
\end{abstract}

\section{Keywords}

Atrazine, Bioaccumulation, Cypermethrin, Heavy Metals, Honey, Plateau State

\section{Introduction}

Honey is very rich in mineral nutrients as it is largely a combination of nutri- 
tional, medicinal and prophylactic (preventative) characteristics. This is due to its different chemical compositions. In order to produce its medicinal efficacy, honey should be devoid of any contaminants [1]. Wide application of pesticides in agricultural practices results from beneficial roles they played in combating various pests and diseases of crops. Several classes of pesticides are distributed in farm sites due to application on land before or during cropping. A ban has been placed on the use of organochlorine pesticides in agriculture due to their persistence and bioaccumulation in the environment. Residues of these pesticides are often times found in [2]. Contamination of different ecosystems can be caused by degradation and excessive application of pesticides by farmers in the environment [3]. The origin of honey could be defined by the quality and quantity of elements in honey. A survey carried out by [4] indicated that component and principal component analyses were considered important tools for differentiating the authenticity of honey samples applying mineral content profile and they stressed the compatibility between the honey type and distribution of elements. Several studies have supported bioaccumulation of pesticide residues from contaminated soil to aerial and root tissues of various plants and organisms [5] [6] [7]. When the nectar of contaminated plants is fed on by bees, several pesticide residues may be transferred to the honey which may affect its quality [3]. Cypermethrin is a synthetic pyrethroid insecticide quantitatively used in agricultural process. It exhibits mode of action by poisoning the nervous system of target organisms. Various studies had suggested that it degraded naturally in soil and plant materials. Its decomposition is facilitated by exposure to sunlight, oxygen and water [8]. Quantified cypermethrin residues in vegetables and obtained higher concentrations of the insecticide beyond the recommended maximum residue limit in 18 samples collected. Due to the sub-acute and chronic toxicity of pesticides, little quantities of their residues in food supply are susceptible to latent risk factor for the health of humans [9]. Potentially, EPA has found atrazine to cause a variety of acute health complications ranging from acute exposures to a concentration that is higher than maximum contamination level. These effects are congestion of the heart, lungs and kidneys; hypertension; antidiuresis; muscle spasms. Other related effects are weight loss and adrenal degeneration [10]. According to Brian [10], atrazine is also found in groundwater environment. The presence of atrazine in well water often times may be due to leaching near the well as a result of atrazine deposit. Maximum residue limits of pesticide residues in honey have been established by European Union which basically is at the limits of quantification of the analytical methods [11].

Bees are capable of carrying contaminants such as heavy metals from contaminated surrounding to the hive, making way for adulteration of the resultant honey produced. [12] emphasized that bee products are contaminated generally by pesticides, heavy metals, bacteria and radioactive substances. Heavy metal composition in honey is remarkably bio-indicators of those environmental toxins. It is reported that between 10,000 to 25,000 honey bee workers make an average of 10 journeys to explore roughly $7 \mathrm{~km}^{2}$ in the area near their hives on dai- 
ly basis which predisposes them to various contaminants [13]. Contaminants of pesticides and heavy metals from agricultural sources are quite challenging problems requiring urgent attention. The wide spread application of agricultural chemicals like pesticides in disease and pests management has given rise to food contamination. A ban has been imposed on some important food substances which cut across several food classes such as beans, sesame seed, melon seed, dried fish, meat, pea nut and palm oil imported from Nigeria in August, 2015, by the European Union governments. Such food substances were examined and determined to have contained high level $(0.03-4.6 \mathrm{mg} / \mathrm{kg})$ of dichlorvos, which was reasonably beyond the maximum residue limit of $0.01 \mathrm{mg} / \mathrm{kg}$ [14]. Bees that feed on the nectar of plants may also transfer pesticide residues from plants or the environment to the hives and ultimately infect the honey. A situation in which hives are treated with pesticides prior to hosting colonies could amount to another source of contamination.

Honey is used by a vast population of people for diversified purposes such as meeting the food requirements or nutrients need and medicinal functions, their contamination may bear severe health hazards [15]. Data on pesticide residues in honey are scanty in most cases and largely unavailable from this particular part of the state that practiced bee farming. To this regard, the present study's objective is to determine pesticide residues and some total heavy metal contents in harvested honey within some major towns in Plateau state, Nigeria.

\section{Materials and Methods}

\subsection{Study Area}

The geographical coordinates of Plateau state are $9^{\circ} 10^{\prime} \mathrm{N}, 9^{\circ} 45^{\prime} \mathrm{E}$ (located between latitude $08^{\circ} 24^{\prime} \mathrm{N}$ and longitude $008^{\circ} 32^{\prime}$ and $010^{\circ} 38^{\prime} \mathrm{E}$.) and has a total area of $30,913 \mathrm{Km}^{2}$ (11,936 Sqm). It is bordered in the North by Kaduna and Taraba States while in the East by Bauchi State and in the West by Nasarawa State. It has a population of about 3.5 million people and it is said to be a miniature Nigeria.

\subsection{Sampling}

Five samples of honey (one litre each) were collected into cleaned bottles from five different farms designated after their spatial location as Bokkos (BKK), Federal College of Forestry (FCF), Plateau Agricultural Development (PAD), Mangu (MGU) and Maraban Jos (MRJ) as shown in modified map of study area (Figure 1). The Honey samples were stored in clear glass bottles wrapped with masking tape and kept away from direct light at room temperature.

Preparation of standard solution was carried out by preparing $1000 \mathrm{mg} \cdot \mathrm{L}^{-1}$ stock solution of each pesticide standard in HPLC grade acetonitrile. The stock solution was diluted to $500 \mathrm{mg} \cdot \mathrm{L}^{-1}$ in same solution, after which a mixture containing $20 \mathrm{~mL}$ of each pesticide standard was prepared. The solutions were then stored at room temperature in amber bottles ready for injection into gas chromatography mass spectrometry (GC-MS). Exactly $2.5 \mathrm{~g}$ of honey sample was 

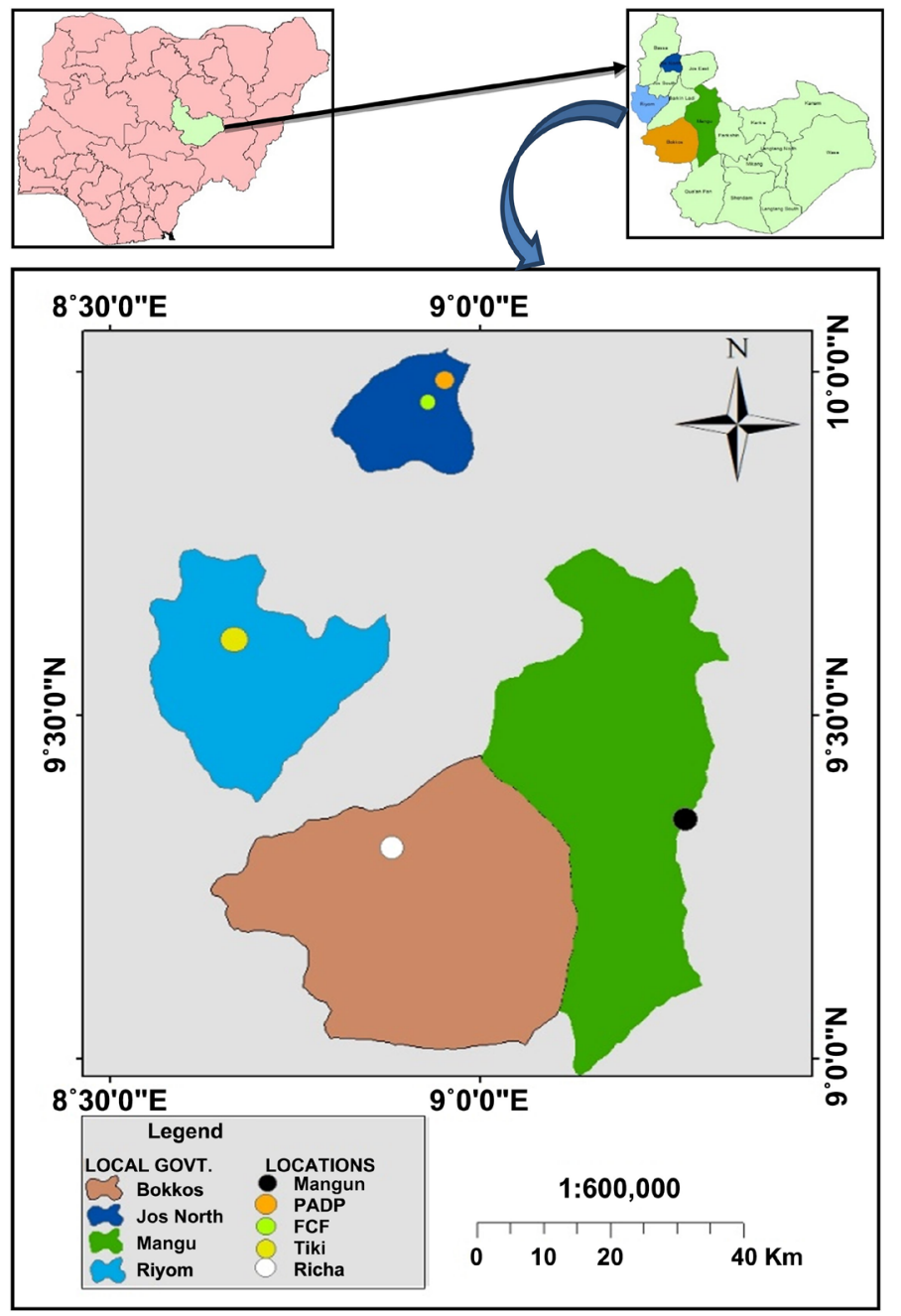

Figure 1. Modified digital map of study area (Source: Digital Map, 2017).

weighed into a $50 \mathrm{~mL}$ tube with cap made of polypropylene. The tube containing the sample was heated at $45^{\circ} \mathrm{C}$ on water bath for one minute to obtain a homogenized sample of honey.

Extraction and clean up were done, in which $5.0 \mathrm{~mL}$ of aqueous $\mathrm{Na}_{2}$ EDTA of $0.1 \mathrm{~mol} \cdot \mathrm{L}^{-1}$ was heated at $45^{\circ} \mathrm{C}$ for one minute and $5 \mathrm{~mL}$ of acetonitrile was added. After shaking the tube for three minutes on vortex shaker, $6.0 \mathrm{~g}$ of anhydrous $\mathrm{MgSO}_{4}$ and $1.5 \mathrm{~g}$ of NaCl were added and then shaken again on vortex shaker for another one minute. The tube was then centrifuged at $2200 \mathrm{rpm}$ for eight minutes which gave a good separation of the phases. The cleanup was performed by dispersive solid phase extraction (D-SPE) in which $2 \mathrm{~mL}$ of the organic phase (supernatant) was used. This step was carried out in a $15 \mathrm{~mL}$ tube made of polypropylene with cap, which contained $120 \mathrm{mg}$ of anhydrous $\mathrm{MgSO}_{4}$ and $100 \mathrm{mg}$ of primary secondary amine (PSA) sorbent. The tube with its contents was shaken on vortex shaker for three minutes, followed by centrifuging at $1800 \mathrm{rpm}$ for eight minutes. At this point, a clean extract (upper Phase) was obtained [16]. 
Analysis of pesticides after calibration of the GC-MS with solution of pesticides standard was carried out by taking $0.95 \mathrm{~mL}$ of the clean extract and injected into the instrument using a $2 \mathrm{~mL}$ vial. The GC-MS used helium gas as the carrier gas. Initial temperature at $80^{\circ} \mathrm{C}$ was held for zero minute, then ramp to $290^{\circ} \mathrm{C}$ at the rate of $1 \mathrm{~mL} /$ minute and held for further five minutes.

\subsection{Determination of Heavy Metals}

Honey samples were digested using standard method adopted from [17]. Mass of honey sample $(1 \mathrm{~g})$ was placed in a $50 \mathrm{~mL}$ beaker and then $10 \mathrm{~mL}$ of concentrated nitric acid was added. The sample was then heated on hot plate until evolution of brown fumes stopped. A volume, $2.5 \mathrm{~mL}$ of hydrogen peroxide was added and then the digest transferred to $100 \mathrm{~mL}$ volumetric flask with deionized water. After centrifugation at $2000 \mathrm{rpm}$ for five minutes, the supernatant solution was analyzed for $\mathrm{Pb}, \mathrm{Cd}, \mathrm{Cr}, \mathrm{Fe}$ and $\mathrm{Mn}$ using atomic absorption spectrophotometer [17].

Statistical Package for Social Sciences (SPSS), 23.0 version was used to analyzed the results; mean, standard deviation and test of significance were carried out using correlation analysis at $\alpha=0.05$.

\section{Results and Discussion}

This research was carried out to determine some pesticide residues and total heavy metal loads in honey within Jos North, Riyom, Bokkos and Mangu local government areas in Plateau state, Nigeria. Results are shown below;

Based on the pesticide audit carried out in the study area; the target pesticides for analysis were atrazine and cypermethrin. A representative GC-MS chromatogram of the two pesticides of interest in honey samples obtained from Mangu farm site is shown in Figure 2.

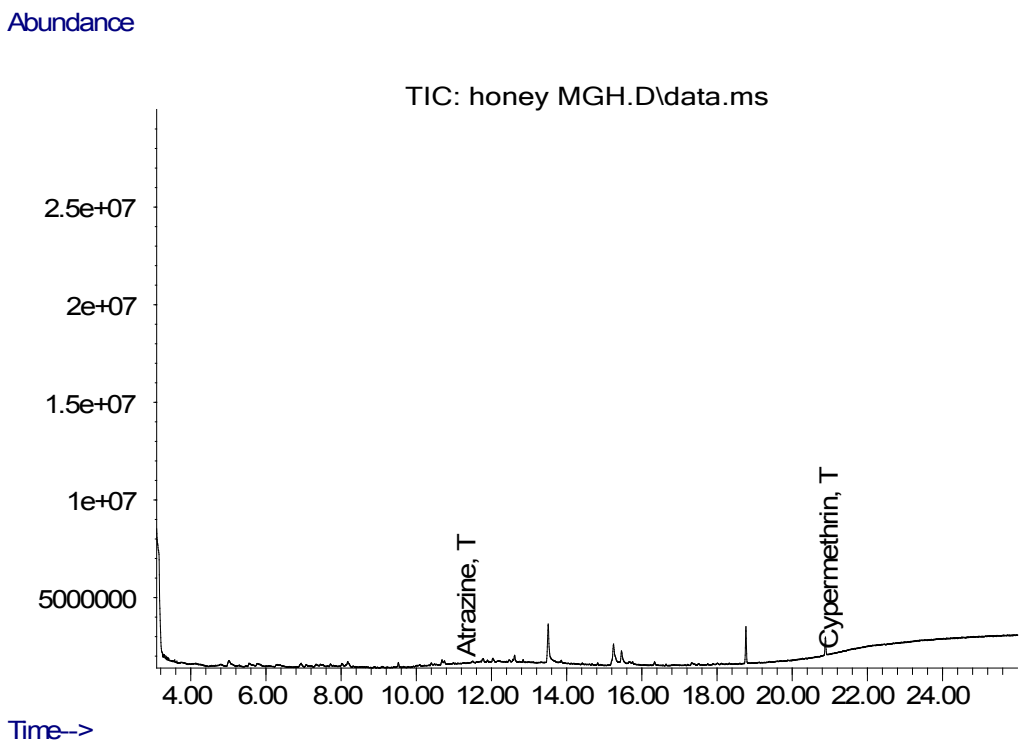

Figure 2. GC-MS chromatogram of pesticides in honey samples from Mangu. 
The result in Table 1 shows the concentrations of atrazine and cypermethrin from the various farm sites under survey within Plateau state. This indicates that atrazine was detected in all the samples analyzed. The result obtained ranged from $0.01-0.36 \mathrm{mg} \cdot \mathrm{kg}^{-1}$ with an average of $0.11 \mathrm{mg} / \mathrm{kg}$. Samples from Bokkos gave the highest value of $0.36 \mathrm{mg} \cdot \mathrm{kg}^{-1}$ while that from Plateau Agricultural Development farm had the lowest value of $0.010 \mathrm{mg} \cdot \mathrm{kg}^{-1}$, which is equal to the EU threshold value. The range of atrazine result obtained fall within the range reported by [18], but higher than the range reported by [16]. Atrazine is a herbicide that is commonly used by farmers in Plateau State, especially in Bokkos and Mangu where Maize and Irish potato are produced in large quantity. Apart from Plateau agricultural development site (PAD), all other results were above the $0.01 \mathrm{mg} \cdot \mathrm{kg}^{-1}$ pesticide maximum residues limit in foods set by European Union. [18] had reported pesticide residues in honey in the range of $0.003-4.3 \mathrm{mg} \cdot \mathrm{kg}^{-1}$ most of which were organochlorine. [16] also reported a range of $0.03-0.09$ $\mathrm{mg} \cdot \mathrm{kg}^{-1}$ for organochlorine pesticide residues in honey. Wisconsin revealed a concentration $\left(\mathrm{mg} \cdot \mathrm{kg}^{-1}\right)$ ranged of $0.002-0.008$ for water and $0.4-20.0$ for extract [19]. The results in Table 1 indicate that all the samples contained cypermethrin residues in the range of $0.11-0.26 \mathrm{mg} \cdot \mathrm{kg}^{-1}$ with an average of 0.176 $\mathrm{mg} \cdot \mathrm{kg}^{-1}$. Sample from Mangu was found to contain the highest value of 0.26 $\mathrm{mg} \cdot \mathrm{kg}^{-1}$ followed by Maraban Jos (MRJ) with $0.22 \mathrm{mg} \cdot \mathrm{kg}^{-1}$, while Plateau agricultural development had the lowest of $0.11 \mathrm{mg} \cdot \mathrm{kg}^{-1}$. The result obtained indicates that cypermethrin level in all the samples were higher than the range reported by other researchers as cited in [16] and [18]. Cypermethrin is an insecticide commonly used in both the urban and rural areas of Plateau State to control insect domestically and on plants. All the results were on the high side compared to the $0.01 \mathrm{mg} \cdot \mathrm{kg}^{-1}$ recommended by European Union, this implies that they were appliesd excessively on the farm and have potency for causing health hazard to ecosysytem. Report on analysis of pyrethroid residue concentration in water and sediment revealed a range of $5 \times 10^{-7}-5 \times 10^{-4} \mathrm{mg} \cdot \mathrm{kg}^{-1}$ for water and $2 \times 10^{-4}-1.0 \times 10^{-1} \mathrm{mg} \cdot \mathrm{kg}^{-1}$ [20]. Environmental protection agency procedure had reported a cypermthrin concentration range of $2.0 \times 10^{-6}-6.0 \times 10^{-6}$ $\mathrm{mg} \cdot \mathrm{kg}^{-1}$ in water and $5 \times 10^{-7}-1.0 \times 10^{-6} \mathrm{mg} \cdot \mathrm{kg}^{-1}$ for sediment using GC-MS. Study of cypermethrin in tomatoes, water and soil gave results of $0.06,1.06,2.44$ $\mathrm{mg} \cdot \mathrm{kg}^{-1}$, respectively and concluded that trends of cypermethrin degradation were fluctuating and slow in tomatoes and fruits while in water and soil it appears regular. However the degradation in soil was the fastest [21].

Table 1. Pesticides concentrations $\left(\mathrm{mg} \cdot \mathrm{kg}^{-1}\right)$ in honeys from five farms in plateau state.

\begin{tabular}{ccccccccc}
\hline S/N & Pesticide & BKK & FCF & PAD & MGU & MRJ & EU & Value \\
\hline 1 & Atrazine & 0.36 & 0.040 & 0.010 & 0.060 & 0.060 & 0.010 & {$[11]$} \\
2 & Cypermethrin & 0.14 & 0.15 & 0.11 & 0.26 & 0.22 & 0.010 & {$[11]$} \\
\hline
\end{tabular}

BKK: Bokkos; FCF: Federal College of Forestry; PAD: Plateau Agricultural Development; MGU: Mangu; MRJ: Maraban Jos; EU: European Union. 


\subsection{Cadmium}

Cadmium was not detected in any sample except that from Maraban Jos which has a value of $0.0013 \pm 0.006 \mathrm{mg} / \mathrm{kg}$. This could be associated with location of Maraban close to main road where heaps of corroded metals from accident vehicles are found and this may be the source of the contamination of the honey with this metal. The value obtained is however lower than the $0.1 \mathrm{mg} / \mathrm{kg}$ maximum limit for cadmium in food set by European legislation [22]. [23] also detected cadmium in honey within same range $\left(0.76-0.005 \mathrm{mg} \cdot \mathrm{kg}^{-1}\right)$ the highest in honey samples obtained from Sulya to the lowest concentration in samples obtained from Kumbalgudu in ten multifloral and five unifloral samples obtained from Sulya, India. Result obtained in this work was lower than that reported by [17] with range $0.02-0.06 \mathrm{mg} / \mathrm{kg}$ of cadmium. Cadmium was quantitatively analysed by using flame atomic absorption spectrophotometer in honey samples in Ethiopia with mean concentration ranged $0.04-0.70 \mathrm{mg} / \mathrm{kg}$. Although these values are higher than the ones obtained from this work, its concentrations in honey samples were not statistically significant from all the sites [24].

\subsection{Chromium}

Chromium level was below detection limit in all the samples analyzed. This could be due to limited sources of the metal within the feeding areas of those honey bees. Chromium is an essential dietary requirement in limited amounts and deficiency can lead to disruption of glucose metabolism. However it is reported that Chromium is carcinogenic. Therefore excessive intake of this metal has an adverse effect as human health [25]. Chromium concentrations $(\mathrm{mg} / \mathrm{kg})$ were reported to be $0.14,0.12$. Analysis of honey was carried out in some towns in India, where chromium contamination was detected; Belgaum (0.14 ppm), Ajjampura $(0.14 \mathrm{mg} / \mathrm{kg})$, Devanahalli $(0.12 \mathrm{mg} / \mathrm{kg})$. Its concentration $(\mathrm{mg} / \mathrm{kg})$ was also found to be 0.11 in Ankola, 0.09 in Honnavar and Bijapur towns, respectively, which were comparatively low [23]. Chromium having mean concentration ranged from $0.16-0.50 \mathrm{mg} / \mathrm{kg}$, was found out in samples of honey examined by [24] in Walmara, where its concentrations in the samples were not statistically significant.

\subsection{Iron}

Iron plays an important role in biology forming complexes with molecular oxygen in hemoglobin. Iron was present in all the samples with range of 0.001$0.005 \mathrm{mg} / \mathrm{kg}$. Samples from Mangu had the lowest value while that from Plateau agricultural development had the highest. Iron is one of the common elements found on earth and can be sourced from dumping and burning of waste [26]. This is shown in Figure 3. Nigerian honeys were characterized by [27] using total reflection $\mathrm{x}$-ray fluorescence technique to determine their physicochemical properties. He found that the concentration of iron $136-407 \mathrm{mg} / \mathrm{kg}$. This result was much higher than the values obtained from this work, which indicated that 


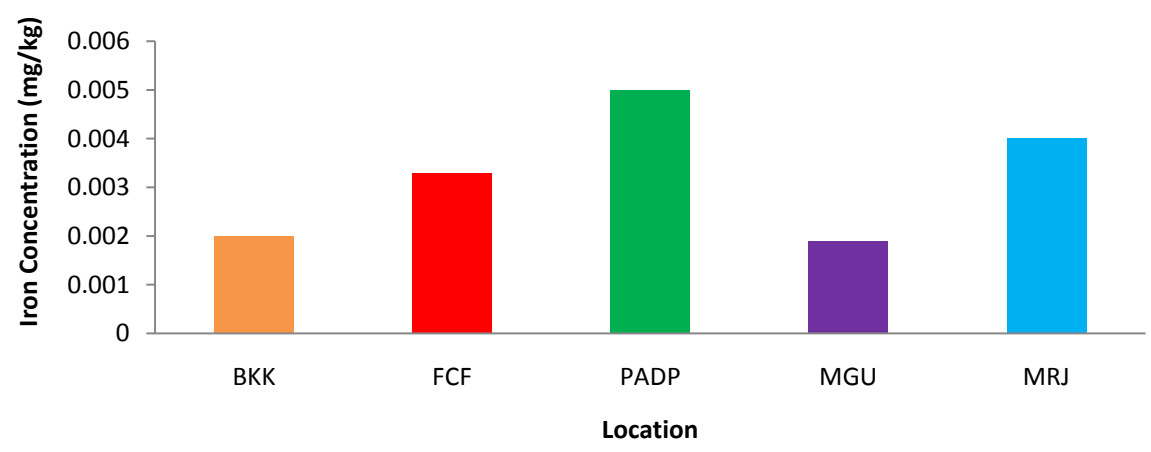

Figure 3. Mean concentration $\left(\mathrm{mg} \cdot \mathrm{kg}^{-1}\right)$ of $\mathrm{Fe}$ in each farm.

irrespective of the sample location, the honey was quite rich in iron being an important part of minerals. Iron was found in some leafy vegetables consumed in Warri region, Nigeria by [28] to be within a range of $10-200 \mathrm{mk} / \mathrm{kg}$ dry weight whereas, the toxic level for man is $200 \mathrm{mg} /$ day. This indicates that it is within the allowable limit. Heavy metals were analysed in honey samples obtained from Walmara in Ethiopia using flame atomic absorption spectrophotometer. Iron was reported to have mean concentration ranged $4.87-11.79 \mu \mathrm{g} / \mathrm{g}$, when quantified by means of UV-visible spectrophotometer. There was significant difference in the concentrations of iron in honey [24]. The absorption of heavy metals in the soil is dependent mainly on soil $\mathrm{pH}$ and organic matter content; therefore, high concentration of heavy metal content in soil does not always reflect a corresponding high value in plants [28].

\subsection{Lead}

The result indicates that out of the samples analyzed, federal college of forestry, Plateau agricultural development and Mangu contained lead in the range of $0.0007-0.0025 \mathrm{mg} / \mathrm{kg}$ while those from Bokkos and Maraban Jos were below detection limit in the sample. This is represented in Figure 4. The absence of the metal in sample from Bokkos could be due to their locations (far) from the main town where many industries are found that might expose the metal. A similar study carried out in urban areas of Bangalore showed a high concentration $(\mathrm{mg} / \mathrm{kg})$ of lead (4.2) while other towns like Pattur, Honnavar, karwar, Sirsi and Siddapur were $3.7,3.2,2.4,2.1$, and 1.9 , respectively. The rural areas of same country such as Sulya, Doddaballapur and Belgaum recorded low concentration [23], this shows a progressive relationship between lead distribution in urban and rural vicinities due to variation in anthropogenic engagements. Three samples were contaminated with lead; however, their levels were lower than the maximum limits set by Food and Agriculture Organization and World Health Organization of $1.5 \mathrm{mg} / \mathrm{kg}$ for lead $(\mathrm{pb})$ in honey. Research carried out by [24] also indicated that most trace metals and all residues have been found to be within the acceptable range set by national and international standards except $\mathrm{Pb}$ and $\mathrm{Cd}$ contents in some samples. Lead was determined to have its mean concentration ranged $0.37-0.90 \mu \mathrm{g} / \mathrm{g}$ in samples of honey from Walmara. Its 


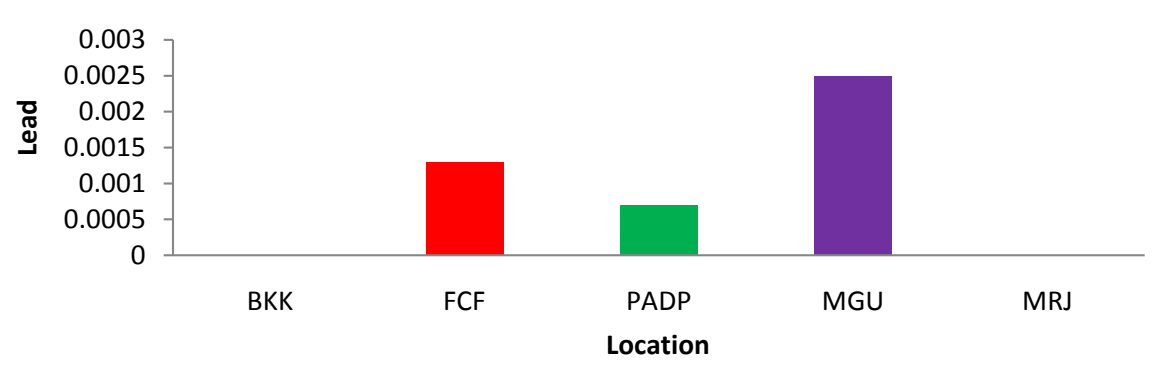

Figure 4. Mean concentration $\left(\mathrm{mg} \cdot \mathrm{kg}^{-1}\right)$ of $\mathrm{Pb}$ in each farm.

concentrations in the honey samples were not statistically significant across sites [17] had reported a ranged of $0.02-0.06 \mathrm{mg} / \mathrm{kg}$ of lead detected in honey sample which are higher compared to the results obtained in this research. Lead a well known metal pollutant can get to the human system through food, water and air. It induces toxicity that can lead to health hazards and is no importance in human metabolism [29]. Previously, most concentrations of lead were from the tailpipes of cars. Since 1973 through 1995, the use of lead in gasoline as additives has been phased out by environmental protection agency (EPA). Barely all the emission of lead compounds presently emanate from mainly stationary sources such as lead smelters and aircraft with piston engines that operate on leaded gasoline, which applications are intended for personal transportation, business and instructional flying [30].

\subsection{Manganese}

Manganese was found in all the samples with an average concentration of 24.322 $\mathrm{mg} / \mathrm{kg}$ and ranged from $15.67-35.19 \mathrm{mg} / \mathrm{kg}$. Sample from federal college of forestry has the highest concentration with a value of $35.19 \pm 0.43 \mathrm{mg} / \mathrm{kg}$, while Mangu has the lowest value of $15.67 \pm 0.13 \mathrm{mg} / \mathrm{kg}$. This is shown in Figure 5 . Honey analyzed was rich in manganese. The sources of their floral nectar which could be rich in that element might be responsible for the high result. [31] had reported manganese range of $0.08 \%-0.088 \%$ for honey which is far lower than result obtained in this analysis. Results of honeys from federal college of forestry and Plateau agricultural development were higher may be because of their location in the metropolis where several activities that facilitate the release of the metal from source such as batteries, glasses, etc are rampant [32].

Correlation analysis was carried out to determine the relationship between heavy metals present. There was negative correlation between cypermethrin and manganese, while there was positive correlation between Iron and manganese, but was not significant. The study revealed the status of honey in the study area in terms of pesticide residues and heavy metal contamination. All the samples were found to be contaminated with pesticide residues (atrazine and cypermethrin) above the maximum residue level recommended by the European Union (apart from Plateau agricultural development site for atrazine concentration). Samples from Bokkos were found to contain the highest concentration of atrazine. 


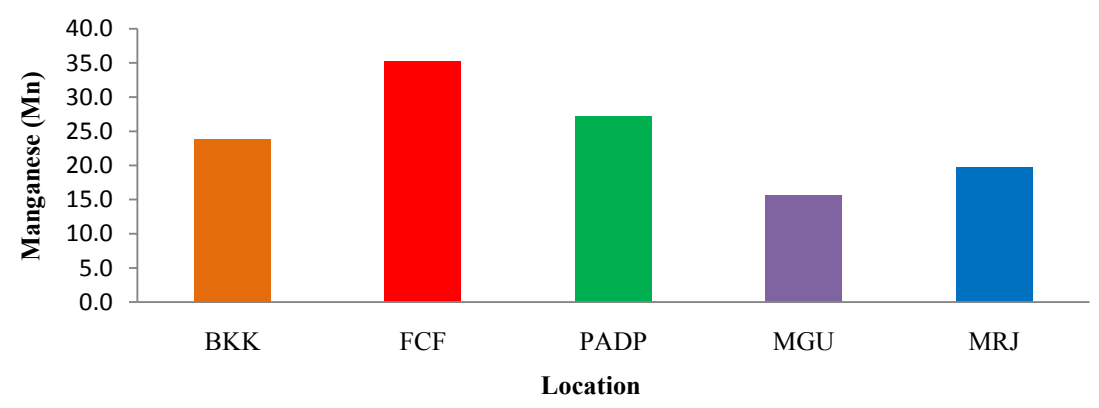

Figure 5. Mean concentration $\left(\mathrm{mg} \cdot \mathrm{kg}^{-1}\right)$ of $\mathrm{Mn}$ in honey samples from selected farms.

Honeys from all the farms were found to contain cypermethrin above the maximum residue level with higher values from Maraban Jos and Mangu. Iron and manganese were found in all the farms but the concentration of manganese was higher. Only Sample from Maraban Jos was found to contain cadmium. Honeys from all the farms contain lead apart from that of Bokkos and Maraban Jos. Chromium was not present in any of the samples analyzed. Concentration of heavy metals found in all the honey samples were below the maximum concentration limits recommended by food and agriculture organization, world health organization, with exception of manganese which exceeded the limits.

\section{Conclusion}

The study revealed that most of the honey samples analyzed contained the selected pesticide residues above the maximum residue levels recommended by European Union, while concentration of heavy metals found in all the samples was below the maximum concentration limits recommended by food and agriculture organization alongside world health organization. Manganese took exception which was on the high side in all the samples. The high concentration of pesticide residues found in the samples indicates contaminated environment in which those bees fed; therefore there should be close monitoring of the quality of honeys produced. Farmers and the general public should be brought to terms on the danger of indiscriminate use of pesticides and the tendency of incremental heavy metal burden in the future even though, there is a temporal relief on the vicinity so investigated. Further research in similar dimension should be extended to neighbouring town to cover more scope of work on this subject matter.

\section{Acknowledgements}

We express our gratitude for the permission granted us by college of forestry, Jos to use their laboratory for this work.

\section{Conflicts of Interest}

The authors declare that there is no conflict of interest.

\section{References}

[1] Solayman, Md., Asiful Islam, Md., Paul, S., Yousuf Ali, Md., Khalil, I., Alam, N. and 
Hua Gan, S. (2016) Physicochemical Properties, Minerals, Trace Elements, and Heavy Metals in Honey of Different Origins: A Comprehensive Review. Comprehensive Reviews in Food Science and Food Safety, 15, 219-233. https://doi.org/10.1111/1541-4337.12182

[2] Meijer, S.N., Shoeib, M., Jantunen, L.M.M., Jones, K.C. and Hamer, T. (2003) Air Soil Exchange of Organochlorine Pesticides in Agricultural Soils. 1. Field Measurement Using a Novel in Situ Sampling Device. Environmental Science \& Technology, 37, 1292-1299. https://doi.org/10.1021/es020540r

[3] Barganska, Z., Slebioda, M. and Namiesnik, J. (2014) Pesticides Residues Level in Honey from Apiaries Located off Northern Poland. Food Control, 31, 196-201. https://doi.org/10.1016/j.foodcont.2012.09.049

[4] Chudzinska, M. and Baralkiewicz, D. (2010) Estimation of Honey Authenticity by Multielements Characteristics Using Inductively Coupled Plasma-Mass Spectrometry (ICP-MS) Combined with Chemometrics. Food and Chemical Toxicology, 48, 284-290. https://doi.org/10.1016/j.fct.2009.10.011

[5] Hoshi, H; Minamoto, N., Iwata, H., Shiraki, K., Tatsukawa, R., Tanabe, S., Fujita, S., Hirai, K. and Kinjo, T. (1998) Organochlorine Pesticides and Polychlorinated Biphenyl Congeners in Wild Terrestrial Mammals and Birds from Chuburegion, Japan: Interspecies Comparison of the Residue Levels and Compositions. Chemosphere, 36, 3211-3221. https://doi.org/10.1016/S0045-6535(98)00011-3

[6] Gonzalez, M., Miglioranza, K.S., Aizpun De Moreno, J.E. and Moreno, V.J. (2003) Organochlorine Pesticides in Leek (Allium porrum) Crops Grown on Untreated Soils an Agricultural Environment. Journal of Agricultural and Food Chemistry, 51, 5024-5029. https://doi.org/10.1021/jf034349s

[7] Hamers, T., Van der Brink, P.J., Moss, L., Van der Linden, S.C., Legler, J., Koeman, J.H. and Murk, A.J. (2003) Estrogenic and Esterase-Inhibiting Potency in Rain Water in Relation to Pesticide Concentrations, Sampling Season and Location. Environmental Pollution, 123, 47-65. https://doi.org/10.1016/S0269-7491(02)00364-0

[8] González-Rodríguez, R.M., Rial-Otero, R., Cancho-Grande, B. and Simal-Gándara, J. (2008) Determinations of 23 Pesticide Residues in Leafy Vegetables Using Gas Chromatography-Ion Trap Mass Spectrometry and Analyte Protectants. Journal of Chromatography A, 1196-1197, 100-109.

https://doi.org/10.1016/j.chroma.2008.02.087

[9] Fong, W.G., Moye, H.A., Seiber, J.N., Toth, J.P. (1999) Pesticides Residues in Foods. In: Fong, W.G., Ed., Methods, Techniques, and Regulations, John Wiley \& Sons, New York, 376 p.

[10] WHO (2003) Atrazine in Drinking-Water Background Document for Development of WHO Guidelines for Drinking-Water Quality. Originally Published in Guidelines for Drinking-Water Quality, 2nd ed., Volume 2, Health Criteria and Other Supporting Information. World Health Organization, Geneva. http://www.who.int

[11] (2014) European Union Pesticides Database. https://op.europa.eu/

[12] Al-Waili, N., Salom, K., Al-Gamdi A. and Ansari, M.J. (2012) Antibiotic Pesticides and Microbiological Contaminants of Honey: Human Health Hazard. The Scientific World Journal, 2012, Article ID: 930849. https://doi.org/10.1100/2012/930849

[13] Rissato, S.R., Galhiane, M.S., de Almeida, M.V., Gerenotti, M. and Apron, B.M. (2007) Multiresidue Determination of Pesticides in Honey Samples by Gas Chromatography-Mass Spectrometry and Application in Environmental Contamination. Food Chemistry, 101, 1719-1726. https://doi.org/10.1016/j.foodchem.2005.10.034

[14] Onuwa, P.O., Eneji, I.S., Itodo, A.U. and Sha'Ato, R. (2017) Determination of Pesti- 
cideResidues in Edible Cropsand Soil from University of Agriculture Makurdi Farm Nigeria. Asian Journal of Physical and Chemical Sciences, 3, 1-17. https://doi.org/10.9734/AJOPACS/2017/35001

[15] Lozowicka, B. (2013) The Development, Validation and Application of a GC-Dual Detector (NPD-ECD) Multi-Pesticide Residue Method for Monitoring Bee Poisoning Incidents. Ecotoxicology and Environmental Safety, 97, 210-222. https://doi.org/10.1016/j.ecoenv.2013.07.010

[16] Orso, D., Manoel, L.M., Filipe, F.D., Tiele, M.R., Magali, K., Adaime, M.B. and Renato, Z. (2014) Multiresidue Determination of Pesticide Residues in Honey by Modified QuEChERS Method and Gas Chromatography with Electron Capture Detection. Journal of Brazilian Chemical Society, 25, 1335-1364.

https://doi.org/10.5935/0103-5053.20140117

[17] Ahmida, M.H.S., Elwefali, S., Agba, A., Elagori, M. and Ahmida, N.H.S. (2013) Physiochemical, Honey Metals and Phenolic Compounds Analysis of Libyan Honey Samples Collected from Benghazi during 2009-2010. Food and Nutrition Sciences, 4, 33-40. https://doi.org/10.4236/fns.2013.41006

[18] Blasco, C., Ferdinandez, M., Pena, A., Lino, C., Silvera, M.I., Font, G. and Pico, Y. (2003) Assessment of Pesticide Residues in Honey Samples from Portugal and Spain. Journal of Agricultural and Food Chemistry, 51, 8132-8138. https://doi.org/10.1021/jf034870m

[19] Steinheimer, T.R. and Ondrus, M.G. (1990) Liquid Chromatographic Determination of Atrazine and Its Degradation Products in Water. U.S. Geological Survey, Water-Resources Investigations Report 89-4193.

[20] Hladik, M.L., Orlando, J.L. and Kuivila, K.M. (2009) Collection of Pyrethroids in Water and Sediment Matrices: Development and Validation of a Standard Operating Procedure. United States Geological Survey, 22 p. Scientific Investigations Report 2009-5012. https://doi.org/10.3133/sir20095012

[21] Amer, A., EL Awami, I.O., Elsiddig, F.I., Aessa, M. and Albanqeeyah, S.A. (2015) Patterns of Natural Degradation of Cypermethrin in Tomato Fruits, Water and Soil under the Desert Environment of Ogla Oasis Cyrenaica-Libya. Journal of Experimental Biology and Agricultural Sciences, 3, 8694. https://doi.org/10.18006/2015.3(5).458.463

[22] EU Council Directive (2002) Council Directive 2001/110/EC of 20 December 2001 Relating to Honey. Official Journal of the European Communities, L10, 47-52.

[23] Singh, C., Shubharani, R. and Sivaram, V. (2014) Assessment of Heavy Metals in Honey by Atomic Absorption Spectrometer. World Journal of Pharmacy and Pharmaceutical Sciences, 3, 509-515.

[24] Kebebe, D., Paulos, A. and Haile, E. (2019) Determination of Physicochemical Properties, Heavy Metals and Pesticide Residues of Honey Samples Collected from Walmara, Ethiopia. International Journal of Advanced Research in Chemical Science (IJARCS), 6, 23-33. https://doi.org/10.20431/2349-0403.0607004

[25] Shekhawat, K., Chatterjee, S. and Joshi, B. (2015) Chromium Toxicity and Its Health Hazards. International Journal of Advanced Research, 3, 167-172.

[26] Nimyel, N.D., Egila, J.N. and Lohdip, Y.N. (2015) The Seasonal Variation of Heavy Metals at Three Dumpsites in Plateau State, Nigeria. African Journal of Natural Sciences, 18, 57-67.

[27] Adebiyi, F.M., Akpan, I., Obiajunwa, E.I. and Olaniyi, H.B. (2004) Chemical/Physical Characterization of Nigerian Honey. Pakistan Journal of Nutrition, 3, 278-281. https://doi.org/10.3923/pjn.2004.278.281 
[28] Obi-Iyeke, G. (2014) Trace Metal Dynamics in Some Leafy Vegetables Consumed in Warri, Niger Delta Region of Nigeria. IJRRAS, 18, 279-284.

[29] Özcan, M.M. and Al Juhaimi, F.Y. (2012) Determination of Heavy Metals in Bee Honey with Connected and Not Connected Metal Wires Using Inductively Coupled Plasma Atomic Emission Spectrometry (ICP-AES). Environmental Monitoring and Assessment, 184, 2373-2375. https://doi.org/10.1007/s10661-011-2123-6

[30] Crowder, J.W. (2002) USEPA APTI 482-Sources and Control of Volatile Organic Compounds" Student Manual. Third Edition, November 2002. USEPA-“HON Inspection Tool" EPA-305-B-97-006, September 1997, 282 p.

[31] Suleiman, A.M.E., Abdelhmiedm, B.A. and Salih, Z.A. (2013) Quality Evaluation of Honey Obtained from Different Sources. Food and Public Health, 3, 137-141.

[32] Oluyemi, E.A., Feujit, G., Oyekunle, J.A.O. and Ogunfowokan, A.O. (2008) Seasonal Variations in Heavy Metal Concentrations in Soil and Some Selected Crops at a Landfield in Nigeria. African Journal of Environmental Science and Technology, 8, 138-147. 